\title{
Analysis of the Competence Factors in Improving Personnel Performance Unit in Reserve Criminal Police Resort Asahan
}

Agus Setyawan, Harmein Nasution, and Nazaruddin Matondang

Magister Management, University of Sumatera, Utara Indonesia

\section{Abstract}

The purpose of this study is to determine the most necessary competence factors involved in the performance of the personnel in the Criminal Unit of Asahan Police Detectives, so then it can be improved. This study also intends to develop education and training development policies to improve the competence of the personnel in the Asahan Criminal Investigation Unit, so then performance can be improved. This research indicates that the most needed competency factor to improve the performance of personnel in the Asahan Criminal Investigation Unit is technical knowledge and the tactical aspects of investigation.

Received: 29 August 2018

Accepted: 18 September 2018

Published: 11 November 2018

Publishing services provided by

Knowledge E

(c) Agus Setyawan et al. This article is distributed under the terms of the Creative Commons Attribution License, which permits unrestricted use and redistribution provided that the original author and source are credited.

Selection and Peer-review under the responsibility of the ICOI-2018 Conference Committee.

\section{G OPEN ACCESS}

Keywords: competency factor, knowledge, skill, attitude, Police Resort Asahan

\section{Introduction}

The performance of the Asahan Criminal Investigation Unit of Asahan Police is inseparable from the availability of Human Resources (HR), who perform tasks in accordance with tupoksinya. The competence of Asahan Criminal Investigation Unit personnel in relation to conducting investigations is very decisive. The competence of the personnel will encourage successful or unsuccessful cases depending, this will improve (or worsen) unit performance. Therefore, it is necessary to select qualified personnel who have competence and expertise in the field of investigation so then the performance of the Criminal Investigation Unit of Asahan Police can be increased. A person achieving high performance in his work finds that this is strongly based on their competence to do with that field of work.

According to facts, the placement of Police personnel, especially those assigned to the Criminal Investigation Unit of Asahan Police, has not been based on the competence of the personnel. This can be seen from the presence of Brimob and Sabhara personnel assigned to the Criminal Investigation Unit, where the tasks of Brimob and Sabhara are very different from Reskrim's duties. In addition, there are still many 
personnel who do not have the training specialization of Criminal Detective Vocational Education, but who are still placed as a member of the Criminal Investigation Unit of Asahan Police.

If the placement of personnel is not in accordance with their individual competence and abilities, then the work becomes a task that will not be resolved as expected. This leads to decreased enthusiasm and decreasing work performance, which makes performance to decline.

\section{Methods}

This research was a descriptive study conducted to find out and explain the actual characteristics studied (Now, 2007). According to Sinulingga (2013), the purpose of descriptive study research is to obtain a profile or to discover the relevant aspects of an interesting phenomenon within a particular organization or group. Meanwhile, according to Nawawi (2003), the descriptive method is a research method that focuses on the problems or phenomena that are actually happening at the time of the research done, before going ahead to describe the factors. The factors investigated were accompanied by a rational and accurate interpretation.

Primary data collection is a systematic and standard procedure used to obtain the necessary data used in research. In this study, the data collection was conducted by census, and by examining all elements of the population one by one. The types of questions used in the questionnaire were non-structured (open) and structured (closed) questions. The methods of data collection were done by distributing questionnaires, observation and a documentation study. To solve the problem mentioned earlier, the steps taken were preliminary research, performance measurement design, the weighting phase, a scoring stage, the analysis phase and concluding discussion.

\section{Results and Discussion}

\subsection{Testing validity and reliability}

This section will explain the validity and reliability of the research, which can be explained as follows: 


\subsubsection{Validity testing}

The criterion used to show the validity of the indicator were chosen by comparing the $r_{\text {count }}$ value with the $r_{\text {table }}$, where the value of $r_{\text {count }}>r_{\text {table }}$ indicator was valid. The results of the validity test can be seen in the following table.

TABLE 1: Validity test.

\begin{tabular}{|c|c|c|c|}
\hline \multirow[t]{2}{*}{ Questioner Item Per Variable } & \multicolumn{2}{|c|}{ Criteria Conclusion } & \multirow[t]{2}{*}{ Result } \\
\hline & $\mathbf{r}_{\text {count }}$ & $\mathbf{r}_{\text {table }}$ & \\
\hline \multicolumn{4}{|l|}{ Knowledge } \\
\hline Knowledge 1 & 0.441 & 0.250 & Valid \\
\hline Knowledge 2 & 0.469 & & Valid \\
\hline Knowledge 3 & 0.472 & & Valid \\
\hline Knowledge 4 & 0.493 & & Valid \\
\hline Knowledge 5 & 0.435 & & Valid \\
\hline \multicolumn{4}{|l|}{ Skills } \\
\hline Skills 1 & 0.559 & 0.250 & Valid \\
\hline Skills 2 & 0.552 & & Valid \\
\hline Skills 3 & 0.539 & & Valid \\
\hline Skills 4 & 0.600 & & Valid \\
\hline Skills 5 & 0.564 & & Valid \\
\hline Skills 6 & 0.460 & & Valid \\
\hline Skills 7 & 0.280 & & Valid \\
\hline \multicolumn{4}{|l|}{ Attitude } \\
\hline Attitude 1 & 0.521 & 0.250 & Valid \\
\hline Attitude 2 & 0.400 & & Valid \\
\hline Attitude 3 & 0.527 & & Valid \\
\hline Attitude 4 & 0.388 & & Valid \\
\hline Attitude 5 & 0.403 & & Valid \\
\hline Attitude 6 & 0.422 & & Valid \\
\hline
\end{tabular}

\subsubsection{Reliability testing}

The criterion used to indicate the reliability of the indicator is to compare the Cronbach Alpha value with the Cronbach Alpha standard calculated value of 0.600 , where the Cronbach Alpha count > Cronbach Alpha Standard (0.600), the indicator is declared reliable. The reliability test results can be seen in the following table. 
TABLE 2: Reliability test results variable.

\begin{tabular}{l|c|c|c|}
\hline Variable & $\begin{array}{c}\text { Cronbach } \\
\text { Alpha count }\end{array}$ & $\begin{array}{c}\text { Cronbach } \\
\text { Alpha } \\
\text { Standard }\end{array}$ & Result \\
\hline Knowledge & 0.701 & 0.600 & Reliable \\
\hline Skills & 0.779 & & Reliable \\
\hline Attitude & 0.704 & & Reliable \\
\hline
\end{tabular}

Source: Primary data processed, 2017.

\subsubsection{Identification key performance indicator (KPI)}

Based on the results of the validity and reliability tests, it is known that all of the attributes that exist in each criterion (Dimension) have been deemed to be valid and reliable, so they can be identified as an initial Key Performance Indicator is as follows:

TABLE 3: Identify KPIs based on the criteria of knowledge, skills and attitudes.

\begin{tabular}{|c|c|c|}
\hline \multirow[t]{2}{*}{ Criteria } & \multicolumn{2}{|r|}{ Attribute } \\
\hline & No. & Questionnaire Statement \\
\hline \multirow[t]{5}{*}{ Knowledge } & $P_{1}$ & $\begin{array}{l}\text { Attended Educational Development Specialization } \\
\text { Inquiry }\end{array}$ \\
\hline & $\mathrm{P}_{2}$ & Having legal knowledge of laws and regulations \\
\hline & $P_{3}$ & Knowledge of both technical and tactical investigation \\
\hline & $\mathrm{P}_{4}$ & $\begin{array}{l}\text { Know and understand SOP administration } \\
\text { investigation }\end{array}$ \\
\hline & $P_{5}$ & $\begin{array}{l}\text { Knowing and mastering the management of criminal } \\
\text { investigations }\end{array}$ \\
\hline \multirow[t]{7}{*}{ Skills } & $\mathrm{K}_{1}$ & $\begin{array}{l}\text { Skill of thinking analytically when conducting an } \\
\text { investigation }\end{array}$ \\
\hline & $\mathrm{K} 2$ & Communicate well \\
\hline & $\mathrm{K}_{3}$ & Adapt to any situation and condition \\
\hline & $\mathrm{K}_{4}$ & Organized planning and in relation to work \\
\hline & $\mathrm{K}_{5}$ & The ability to make decisions quickly \\
\hline & K6 & Team up to get things done \\
\hline & $\mathrm{K}_{7}$ & $\begin{array}{l}\text { Builds good relationships with any party related to } \\
\text { their work }\end{array}$ \\
\hline \multirow[t]{6}{*}{ Attitude } & S1 & Physically and mentally healthy \\
\hline & S2 & No criminal problems \\
\hline & $\mathrm{S}_{3}$ & Being able to control themselves \\
\hline & S4 & Have good integrity associated with the task \\
\hline & $\mathrm{S}_{5}$ & Responsible and confident \\
\hline & S6 & Objective in every investigation \\
\hline
\end{tabular}




\subsubsection{Weighted between the KPI criteria}

The first thing to do is to calculate the importance of the Key Performance Indicator Criteria. The weighting between the Key Performance Indicator criteria are as follows.

TABLE 4: Weighted recapitulation between KPI criteria.

\begin{tabular}{|l|c|c|c|}
\hline Criteria & Knowledge & Skills & Attitude \\
\hline Knowledge & 1 & 3 & 5 \\
\hline Skills & 0.33 & 1 & 4 \\
\hline Attitude & 0.20 & 0.25 & 1 \\
\hline Total & $\mathbf{1 . 5 3}$ & $\mathbf{4 . 2 5}$ & $\mathbf{1 0}$ \\
\hline Source: Data Processed, 2017. & & & \\
\hline
\end{tabular}

After weighting the existing KPI criteria, the normalization of the weighting was done. The results of the normalization can be seen as follows.

TABLE 5: Normalization weighted between the KPI criteria.

\begin{tabular}{|l|c|c|c|c|c|}
\hline Criteria & Knowledge & Skills & Attitude & Total & $\begin{array}{c}\text { Priority } \\
\text { Vector }\end{array}$ \\
\hline Knowledge & 0.65 & 0.70 & 0.50 & 1.85 & 0.62 \\
\hline Skills & 0.22 & 0.24 & 0.40 & 0.86 & 0.29 \\
\hline Attitude & 0.13 & 0.06 & 0.10 & 0.29 & 0.09 \\
\hline Total & $\mathbf{1 . 0 0}$ & $\mathbf{1 . 0 0}$ & $\mathbf{1 . 0 0}$ & $\mathbf{3 . 0 0}$ & $\mathbf{1 . 0 0}$ \\
\hline
\end{tabular}

Source: Data processed, 2017.

Having known the value of normalization and the priority vector value, the next step was to determine the maximum value of the eigenvalue ( $\lambda \max$ ) obtained from the number of eigenvalues of the nth PI with the number of PI until-n. Before calculating the value of $\lambda \max$, then first came the multiplication of the matrix based on the value listed in Table 5 . The calculation of the matrix can be seen as follows:

$$
\begin{aligned}
\text { Knowledge } & =(1 \times 0.62)+(3 \times 0.29)+(5 \times 0.09) \\
& =0.62+0.87+0.45 \\
& =1.94 \\
\text { Skill }= & (0.33 \times 0.62)+(1 \times 0.29)+(4 \times 0.09) \\
= & 0.20+0.29+0.36 \\
= & 0.85
\end{aligned}
$$




$$
\begin{aligned}
\text { Attitude } & =(0.20 \times 0.62)+(0.25 \times 0.29)+(1 \times 0.09) \\
& =0.12+0.07+0.09 \\
& =0.28
\end{aligned}
$$

After getting the matrix multiplication value, next was to calculate the maximum value ( $\lambda \max$ ). Calculation of $\lambda \max$ value is as follows:

$$
\begin{aligned}
& \lambda \max =\frac{(1.94 / 0.62)+(0.85 / 0.29)+(0.28 / 0.09)}{3} \\
& \lambda \max =\frac{3.13+2.93+3.11}{3} \\
& \lambda \max =3.05
\end{aligned}
$$

After the $\lambda$ max value was known, the next step was to calculate the value of $\mathrm{Cl}$ (Consistence Index), which was calculated as follows:

$$
\begin{aligned}
& C I=\frac{\lambda \max -n}{n-1} \\
& C I=\frac{3.05-3}{3-1} \\
& C I=0.025
\end{aligned}
$$

After knowing the value of Consistence Index, we then counted the value of Consistence Ratio. Calculation of Consistence Ratio (CR) value is as follows:

$$
C R=\frac{C I}{R I}
$$

The value of RI (Random Index) was obtained from an experiment by Oak Ridge National Laboratory, which was later developed by Wharton School. Based on the experiment, the value of RI with $n$ value of 3 was 0.58 . The value of $C R$ is as follows:

$$
\begin{gathered}
C R=\frac{0.025}{0.58} \\
C R=0.04
\end{gathered}
$$

According to Saaty (1996), values are considered to be consistent when the consistency value (CR) is less than 0.1. Based on these calculations, the level of interest of the respondents is considered to be consistent. Based on existing calculations, note that the largest Priority Vector value is Knowledge. The value of the Priority Vector of Knowledge is equal to 0.62 . This implies that the Criteria of the Competence of Reskrime Personnel that takes precedence is knowledge. 


\subsubsection{Weighted interconnection of KPI attribute}

The Matrix calculation results of the interconnection of the KPI Attributes can be seen as follows.

TABLE 6: Matrix Calculation results.

\begin{tabular}{|c|c|c|c|c|c|c|c|c|c|c|c|c|c|c|c|c|c|}
\hline Attribute & $P_{1}$ & $P_{2}$ & $P_{3}$ & $\mathrm{P}_{4}$ & $P_{5}$ & $\mathrm{~K}_{1}$ & $\mathrm{~K}_{2}$ & $\mathrm{~K}_{3}$ & $\mathrm{~K}_{4}$ & $\mathrm{~K}_{5}$ & K6 & $\mathrm{K}_{7}$ & $\mathrm{~S}_{1}$ & S2 & $\mathrm{S}_{3}$ & $\mathrm{~S}_{4}$ & $\mathrm{~S}_{5}$ \\
\hline $\begin{array}{l}\text { Matrix } \\
\text { Calcula- } \\
\text { tion } \\
\text { Result }\end{array}$ & 0.57 & 0.74 & 9.14 & 6.27 & 0.8 & 0.76 & 5.04 & 6.25 & 6.81 & 3.7 & 7.79 & 1.43 & 6.76 & 1.4 & 3.69 & 6.81 & 3.69 \\
\hline
\end{tabular}

After getting the matrix multiplication value, next was calculate the maximum value ( $\lambda$ max). Calculation of the $\lambda$ max value was as follows:

$$
\lambda \max =\frac{(0.57 / 0.01)+(0.74 / 0.01)+(9.14 / 0.16)+\cdots+(1.39 / 0.02)}{18}=20.85
$$

After the $\lambda \max$ value became known, the next stage was to calculate the value of $\mathrm{Cl}$ (Consistence Index), which can be calculated as follows:

$$
\begin{gathered}
C I=\frac{\lambda \max -n}{n-1} \\
C I=\frac{20.85-18}{18-1} \\
C I=0.17
\end{gathered}
$$

After learning the value of the Consistence Index, we then counted the value of the Consistence Ratio. The calculation of the Consistence Ratio (CR) value was as follows:

$$
C R=\frac{C I}{R I}
$$

The value of the RI (Random Index) was obtained from an experiment by Oak Ridge National Laboratory, which was later developed by Wharton School. Based on the experiment, the value of RI with $n$ value of 18 was 1.76. the value of CR is as follows:

$$
\begin{aligned}
& C R=\frac{0.17}{1.76} \\
& C R=0.09
\end{aligned}
$$

According to Saaty (1996), values are considered to be consistent when the consistency value (CR) is less than 0.1. Based on these calculations, the level of interest of the respondents is considered consistent. 
TABLE 7: Tabular attribute highest key performance indicator.

\begin{tabular}{|c|c|c|}
\hline \multirow{2}{*}{$\begin{array}{l}\text { Key Performance Indicator } \\
\text { Highest }\end{array}$} & \multicolumn{2}{|r|}{ Attribute } \\
\hline & No. & Questionnaire Statement \\
\hline & $P_{3}$ & $\begin{array}{l}\text { Knowledge both technical and tactical about } \\
\text { investigation }\end{array}$ \\
\hline & K6 & Work together in teams to get things done \\
\hline & $\mathrm{K} 4$ & Planning and organizing in work \\
\hline & $S_{4}$ & Have good integrity associated with the task \\
\hline & $\mathrm{P}_{4}$ & $\begin{array}{l}\text { Know and understand SOP administration } \\
\text { and investigations }\end{array}$ \\
\hline & $\mathrm{K}_{5}$ & The ability to make decisions quickly \\
\hline
\end{tabular}

Based on the existing Priority Vector calculation, they can be arranged into the Key Performance Indicator attributes with the largest Priority Vector value as follows:

Based on the calculations conducted in the research, note that the greatest attitude was Knowledge. The Priority Vector of Knowledge was 0.62 . This was followed by Skills, with a Priority Vector value of 0.29 . The last one was Attitude, which had a Priority Vector value of 0.09 . This shows that the competence of a preferred Criminal Investigator is in terms of knowledge first, followed by skills and attitude.

The highest Priority Vector in the skill aspect was the $\mathrm{K} 6$ attribute that is the ability to work together in the team to complete the task. The highest Priority Vector of the Attitude aspect was attribute $\mathrm{S}_{4}$, where good integrity is associated with the task.

In accordance with the aforementioned results, the personnel of the Criminal Investigation Unit of Asahan Police must have competencies that are not in accordance with those required as an investigator. Therefore it is necessary to increase competence in these personnel so as to improve the performance of the personnel of the Criminal Investigation Unit of Asahan Police. Increased competence can be done by providing an Educational Specialization in relation to Criminal Investigation (Dikbangspes Reskrim), with material that needs to be top priority and about technical as well as tactical investigation.

\subsubsection{Conclusion}

1. The most needed competency factors in relation to the performance of personnel in the Asahan Criminal Investigation Unit of Asahan Police that can be improved are aspects of knowledge related to technical as well as tactical investigation, 
aspects of skill related to teamwork and attitude aspects related to personnel integrity.

2. Education and training is needed for the personnel to improve their competence, namely Dikbangspes Reskrim to improve their knowledge, especially about technical and tactical investigation. In addition, training to improve the skills of personnel, especially about teamwork, is important as well as having an educationbased mental revolution to improve the integrity of the personnel.

\section{Acknowledgements}

The authors are grateful to the University of North Sumatra, especially the to the Masters of Management Program team.

\section{Funding}

The authors conducted this research using their own funds meeting the terms and requirements for completing the degree of Magister of Management.

\section{References}

[1] Bacal, R. (2005). Performance Management. Jakarta: PT. Gramedia Pustaka.

[2] Wahyudi, B. (2002). Human Resource Management. Bandung: Sulita Publisher.

[3] Cahyono. (1999). Work Experience in Organizational Management. Jakarta: Gunung Agung.

[4] Prihatini, D. (2012). Analysis of placement factors of human resource on job performance of health officer of Kediri City. Journal of Management Science, Revitalization, vol. 1, no. 3, pp. 57-68.

[5] Nisak, F. (2015). The Influence of Knowledge, Skills, Self Concept and Personal Characteristics of Staff Performance At SMK Negeri Seek Kota Pekalongan. Scientific Work, Semarang State University, Semarang.

[6] Ghozali, I. (2006). Application of Multivariate Analysis With SPSS Program. Semarang: Undip.

[7] Hasan. (2003). Role of Education on Quality of Human Resources. Solo: Publisher of Science.

[8] Hasanuddin. (2006). Education in Competition. Jakarta: Publisher Mandar Maju. 
[9] Hasibuan, M. S. P. (2004). Human Resources Management (revised edition). Jakarta: Bumi Aksara.

[10] Hasibuan, M. S. P. (2009). Human Power Management (tenth printing). Jakarta: Earth Publisher Aksara.

[11] Yuliastuti, I. (2007). The Influence of Knowledge, Skills and Attitudes toward Nurse Performance in Management of Avian Influenza Case in RSUP H. Adam Malik, Year 2007. Thesis, University of North Sumatra, Medan.

[12] Jamaluddin. (2014). The Influence of Education, Ability, Experience and Expertise on Working Perspent of Civilian Police Unit at Gowa District Education Office. Thesis, Universitas Muslim Indonesia, Makassar.

[13] Kriyantono, R. (2007). Practical Techniques for Communication Research: With Examples of Media Research, Public Relations, Marketing Communications and Organizations, (second printing). Jakarta: Kencana Prenada Media.

[14] Mangkunegara, A. P. (2005). HR Performance Evaluation. Bandung: PT. Refika Aditama.

[15] Mathis, R. L. and Jackson, J. H. (2006). Human Resources Development. Literacy Achievement. Jakarta.

[16] Nasution, H. and Soetadi, I. (2012). Human Resources Based on Competence. Medan: USU Press.

[17] Nawawi, H. (2003). Social Research Methods. Yogyakarta: Gajah Mada University Press.

[18] Nawawi, H. (2008). Strategic Management of Nonprofit Organizations on Governance. Yogyakarta: Gajah Mada University Press.

[19] Nazir. (2009). Research Methods. Jakarta: Ghalia Indonesia.

[20] Notoatmodjo, S. (2003). Education and Health Behavior. Jakarta: Rineka Cipta.

[21] Polak, Y. S. (2012). The Influence of Education Level, Work Skills and Work Attitude to Employee Performance of PT Bank Negara Indonesia (Persero), Tbk Makassar Branch. Scientific Work, Hasanuddin University, Makassar.

[22] Prihatini, D. (2012). Analysis of Human Resources Placement Policy Factors on Job Performance of Health Officials of Kediri City. Journal of Management Science Revitalization, vol. 1, no. 3, Pp. 57-66.

[23] Rahmawati, P. (2012). Employee Performance Analysis of Health Office of Regency of Bintan Province of Kepulauan Riau Province in 2012. Thesis, Master Program in Public Health Sciences. Faculty of Public Health. University of Indonesia, Jakarta. 
[24] Veithzal, R. (2009). Human Resource Management, For Companies From Theory to Practice (second edition). Jakarta: PT. Rajawali Grafindo Persada.

[25] Sabri, M. A. (2008). Introduction to Educational Science. Jakarta: UIN Jakarta Press.

[26] Sastrohadiwiryo, S. B. (2002). Indonesian Manpower Management (second edition). Jakarta: PT. Bumi Aksara.

[27] Sinulingga, S. (2015). Research Methods (third edition). Medan: USU Press. 